\title{
PROLETARIANISASI PEKERJA SOSIAL DALAM TATANAN BIROKRASI
}

\author{
Agustinus M.H. Making1, M. Fadhil Nurdin ${ }^{2}$ \\ Pascasarjana FISIP Universitas Padjadjaran \\ agustimaking@gmail.com
}

\begin{abstract}
ABSTRAK
Penelitian ini mengkaji tentang hubungan birokrasi dengan masalah pemberian gaji, jaminan, dan tunjangan bagi pekerja sosial. Metode yang digunakan adalah kualitatif. Teknik pengumpulan data yang digunakan meliputi wawancara, observasi, dan dokumentasi. Hasil penelitian ini menunjukkan bahwa pekerja sosial mengalami proletarianisasi, karena keterlambatan pemberian gaji bulanan, ketidakcukupan besaran gaji, serta ketiadaan jaminan dan tunjangan. Proletarianisasi ini terjadi karena mekanisme birokrasi yang tidak transparan.
\end{abstract}

Kata kunci: Pekerja Sosial, Birokrasi, Kelas, Proletarisasi

\begin{abstract}
This research examines the relationship between bureaucracy and the problem of providing salaries, social insurance for social workers. The method used is qualitative. Data collection techniques based on interviews, observation, and documentation. The results of this research show that social workers experience proletarianization, due to delays in the provision of monthly salaries, inadequate salary levels, and lack of social insurance. This proletarianization occurs because the mechanism of bureaucracy is not transparent.
\end{abstract}

Keywords: Social Workers, Bureaucracy, Class, Proletarianization

2. Pascasarjana FISIP Universitas Padjadjaran
m.fadhil.nurdin@unpad.ac.id 


\section{PENDAHULUAN}

Dalam berbagai literatur pekerjaan sosial Indonesia, sulit ditemukan penjelasan tentang sejarah perkembangan profesi pekerja sosial di Indonesia. Damanik (2008) dan Soehartono (2003), misalnya, lebih tertarik untuk menjelaskan sejarah dari profesi pekerja sosial di Amerika Serikat. Berdasarkan hasil penelusuran penulis, literatur yang kurang lebih dapat digunakan untuk menjelaskan sejarah perkembangan profesi pekerja sosial di Indonesia adalah sebuah buku yang ditulis oleh Fahrudin (2012), serta beberapa undang-undang tentang kesejahteraan sosial dan pekerjaan sosial.

Fahrudin (2012) menjelaskan bahwa pada masa pemerintahan kolonial Belanda, penyelenggaraan pelayanan kesejahteraan sosial lebih banyak dilakukan oleh lembaga keagamaan dan lembaga kemasyarakatan (bukan oleh pemerintahan kolonial Belanda). Sedangkan pada masa pemerintahan kolonial Jepang, penyelenggaraan pelayanan kesejahteraan sosial dilaksanakan oleh Guinsikanbu Naimubu (Departemen Dalam Negeri Jepang) dan berfokus pada para romusha (orang-orang yang dipekerjakan secara paksa) di berbagai wilayah jajahan Jepang di Indonesia.

Setelah masa kemerdekaan, penyelenggaraan usaha kesejahteraan sosial semakin terstruktur melalui pengesahan Undang-Undang (UU) Nomor 6 Tahun 1974 tentang Ketentuan-Ketentuan Pokok Kesejahteraan Sosial. Dalam UU tersebut, terdapat istilah tenaga pekerjaan sosial profesional. Meski demikian, dalam UU tersebut, tidak ada kriteria dan kualifikasi dari tenaga pekerjaan sosial profesional. Lalu pada tahun 2009, UU Nomor 11 Tahun 2009 tentang Kesejahteraan Sosial disahkan. Dalam UU inilah, terdapat istilah beserta kualifikasi Pekerja Sosial Profesional muncul. Pada pasal 24 UU ini, tertulis bahwa penanggungjawab dari penyelenggaraan pelayanan kesejahteraan sosial ialah pemerintah pusat dan pemerintah daerah. Tugas menteri dan/atau Kementerian Sosial dalam pelaksanaan tanggungjawab itu adalah merumuskan kebijakan dan program-program kesejahteraan sosial.

Kemudian pada tahun 2019, pemerintah mengesahkan UU Nomor 14 Tahun 2019 tentang Praktik Pekerjaan Sosial. Dalam UU ini, tercantum dengan jelas mengenai tugas pekerja sosial, standar prosedur operasional, standar kompetensi, hak dan kewajiban pekerja sosial, organisasi pekerja sosial, serta pengurusan ijin praktik pekerjaan sosial. Pengesahan UU ini merupakan langkah awal agar peran pekerja sosial dalam pelaksanaan program-program kesejahteraan sosial dapat semakin dikenal oleh masyarakat.

Pelaksanaan program-program kesejahteraan sosial di Indonesia umumnya dilaksanakan pemerintah melalui Kementerian Sosial, Dinas Sosial provinsi/kabupaten, dan lembaga- 
lembaga kesejahteraan sosial. Para pekerja sosial selalu menjadi aktor utama dalam pelaksanaan program-program kesejahteraan sosial di Indonesia (Fahrudin, 2012).

Goodsell (2005) mengemukakan bahwa istilah 'biro' merujuk pada kementerian, departemen (dinas), atau sub-unit dari sektor publik yang menggunakan-sekaligus bertanggung jawab atas-keuangan publik (public expanse). Keuangan publik dalam konteks ini meliputi anggaran pendapatan dan belanja negara/daerah (APBN/APBD). Sedangkan istilah birokrasi merujuk pada sistem administrasi yang terkait dengan pejabat dan aturan dalam pemerintahan (Abercombie, dkk. 2010; Boudon \& Bourricaud, 1989). Secara umum, program kesejateraan sosial dilaksanakan melalui mekanisme birokrasi (Anderson \& Martin, 1983). Selain itu, pemberian gaji, jaminan, dan tunjangan bagi pekerja sosial juga diatur oleh mekanisme birokrasi (Ellis, 2007).

Masalah-masalah tentang keterlambatan pembayaran gaji, ketidakcukupan besaran gaji, ketiadaan jaminan sosial, dan ketiadaan tunjangan bagi para pekerja sosial profesional yang bekerja dalam program-program kesejahteraan sosial masih sering terjadi. Masalah ini jarang didiskusikan dan/atau diteliti dalam ranah akademik. Riset ini merupakan sebuah upaya kecil untuk membawa masalah ini secara kritis ke dalam ranah akademik.

\section{METODE PENELITIAN}

Metode penelitian yang digunakan adalah kualitatif. Data-data dikumpulkan melalui wawancara mendalam, observasi, dan dokumentasi (buku-buku, jurnal, dan koran digital). Proses pengumpulan data dilakukan pada bulan Agustus hingga September tahun 2017. Informan utama dalam penelitian ini berjumlah empat orang yang bekerja sebagai pekerja sosial profesional dalam pelaksanaan program-program kesejahteraan sosial. Sedangkan informan pendukung berjumlah dua orang yang berijazah pendidikan pekerjaan sosial yang enggan bekerja sebagai pekerja sosial profesional. Data-data kemudian dianalisis dengan menggunakan model interaktif yang meliputi penyajian data, reduksi data, dan penarikan kesimpulan (Miles \& Huberman, 1992).

\section{KERANGKA TEORI/KONSEP}

\section{Birokrasi}

Birokrasi merupakan sebuah bentuk administrasi yang paling baik demi mencapai sebuah tujuan yang rasional dari sebuah organisasi atau institusi (Weber, 1946; 1978). Secara struktural, birokrasi meliputi pembagian kerja, sistem personalia dalam rekrutmen pekerja (pegawai atau karyawan) dan karir, otoritas yang hirarkis dari atasan terhadap bawahan, serta jejaring kerjasama dan informasi yang menghubungkan para pekerja (Trikha, 2009). Birokrasi menciptakan 
rasionalisasi melalui peraturan yang 'dianggap adil dan logis' oleh para anggota organisasi (pegawai atau karyawan). Aturan-aturan ini menentukan sarana untuk mencapai tujuan organisasi yang berbasis pada pengetahuan teknis, dan mengarahkan perilaku anggota organisasi. Hal ini disebut sebagai rasionalisasi birokrasi (Weber, 1946; 1978; Abercombie, dkk. 2010). Karakteristik birokrasi menurut Weber $(1946 ; 1978)$ adalah sebagai berikut:

1) Kewajiban-kewajiban pekerja (pegawai atau karyawan) secara resmi ditetapkan oleh hukum, peraturan, atau langkah-langkah administratif.

2) Bersifat hirarkis dan terintegrasi dalam satu sistem perintah, sehingga otoritas dikontrol oleh atasan yang membuat suatu keputusan terhadap bawahan.

3) Terdapat aktivitas yang diarahkan oleh aturan-aturan tertulis.

4) Terdapat pelatihan dan magang bagi para pekerja baru yang dilakukan oleh para ahli.

5) Segala pekerjaan yang dilakukan menuntut loyalitas dan kapabilitas. Karakter ini biasa berlaku pada institusi atau organisasi yang melaksanakan tujuan-tujuan kerja bersifat jangka panjang.

6) Setiap bidang kerja atau jabatan membutuhkan keahlian dan pengetahuan tertentu Melalui birokrasi, para pegawai 'ditugaskan' oleh suatu otoritas dari atasan yang superior. Besaran gaji dalam tatanan birokrasi diberi secara hirarkis berdasarkan 'status' (jabatan/ ranking), dan berdasarkan periode waktu bekerja. Para pegawai atau karyawan juga menerima kompensasi atau tunjangan (variable pay) dan jaminan hari tua (Weber, 1946; 1978; Lefort, 1986). Dalam tatanan birokrasi yang bersifat hirarkis tersebut, para pegawai atau karyawan dengan jabatan yang rendah berusaha mencapai jabatan yang tinggi (karier) demi mendapatkan gaji yang tinggi. Hal ini sering terjadi pada negara-negara yang tidak memberikan peluang bagi para pegawai atau karyawan dengan jabatan yang rendah. Di beberapa negara, situasi ini identik dengan pemberian gaji yang rendah bagi para pegawai (Weber, 1946; Lefort, 1986).

\section{Kelas dan Proletarianisasi}

Secara umum, dalam pandangan Marx (2010c; 1968), terdapat tiga kelas dalam masyarakat, yakni kelas pemilik modal, kelas pekerja, serta kelas menengah. Pemilik modal (kapitalis) menguasai kepemilikan alat produksi dan mempekerjakan para pekerja (buruh) dalam waktu kerja tertentu. Sedangkan para pekerja hanya memiliki tenaga yang digunakan bekerja (labour power). Tenaga dari para pekerja itu digunakan untuk memproduksi komoditas. Karena tenaga dari pekerja telah dikeluarkan, maka para pemilik modal pun memberi upah kepada para pekerja berdasarkan waktu kerja (Marx, 2010a).

Nilai dari suatu komoditas (value) ditentukan oleh tenaga yang dikeluarkan oleh pekerja dalam waktu kerja tertentu. Misalnya, nilai dari sepasang sepatu ditentukan oleh tenaga yang 
dikeluarkan oleh para pekerja selama 8 jam kerja. Nilai dari komoditas kemudian termanifestasikan dalam bentuk nilai tukar (exchange value) atau harga. Secara umum, pemilik modal mendapat keuntungan atau nilai lebih (surplus value) melalui pemberian upah yang tak sesuai waktu kerja, dan penambahan waktu kerja dengan upah yang tetap (Marx, 2010a). Hal ini merupakan bentuk eksploitasi pemilik modal terhadap pekerja. Dalam konteks ini, keuntungan terutama diperoleh dari pekerja yang mendapat upah rendah dan dikontrak dalam periode tertentu (Bottomore, 1991). Ketika keuntungan makin meningkat, maka akan ada akumulasi modal (Marx, 2010a).

Posisi kelas menengah (middle class) berada di antara kelas pemilik modal dan kelas pekerja (buruh). Kelas menengah sering dianggap sebagai kelas yang tidak produktif (unproductive labour), karena tidak memproduksi komoditas, dan hanya menghasilkan jasa atau pelayanan. Kelas menengah umumnya meliputi pegawai dan para karyawan yang bekerja secara administratif di institusi dan lembaga, baik swasta maupun negara (Bottomore, 1991; Gough, 1972; Wright, 2009).

Menurut Gough (1972), semua orang yang memproduksi komoditas (kelas pekerja) maupun yang tidak memproduksi komoditas (kelas menengah) sama-sama dapat dieksploitasi. Perbedaannya ialah bahwa kelas pekerja bekerja kepada pemilik modal dalam kegiatan produksi komoditas; sedangkan kelas menengah bekerja kepada negara (institusi pemerintahan) atau lembaga swasta dalam kegiatan menghasilkan jasa atau pelayanan (Bottomore, 1991; Gough, 1972; Wright, 2009).

Proletarianisasi adalah sebuah proses ketika sebagian kelas menengah secara efektif terserap ke dalam kelas pekerja (Abercombie, dkk, 2010). Hal ini berarti bahwa kelas menengah akan semakin tereksploitasi seperti kelas pekerja, karena kelas pekerja dan kelas menengah sama-sama bekerja (mengeluarkan tenaga) untuk mendapatkan upah (Tilly, 1979). Dalam konteks ini, bentuk eksploitasi yang terjadi pada kelas pekerja dan kelas menengah meliputi pemberian upah yang tak sesuai waktu kerja, penambahan waktu kerja dengan upah yang tetap, dan tidak adanya jaminan serta tunjangan (Wright, 2009). Melalui proletarianisasi, kelas menengah akan menjadi kelas pekerja baru dalam bidang jasa atau pelayanan yang dijalankan oleh negara atau lembaga swasta (Tilly, 1979; Bottomore, 1991; Wright, 2009).

Corrigan dan Leonard (1978) menyampaikan bahwa pekerja sosial adalah bagian dari kelas menengah yang telah terproletarianisasi, karena pekerja sosial tetap bekerja (mengeluarkan tenaga) untuk menghasilkan jasa atau pelayanan. Itulah sebabnya, pekerja sosial dapat 
dikategorikan sebagai kelas pekerja yang bekerja atas nama institusi pemerintahan (negara) dan/atau lembaga-lembaga kesejahteraan sosial swasta (Corrigan \& Leonard, 1978).

Dengan demikian, secara keseluruhan, penulis akan menggunakan konsep birokrasi untuk menjelaskan bagaimana masalah keterlambatan pembayaran gaji, ketidakcukupan besaran gaji, dan ketiadaan jaminan serta tunjangan bagi para pekerja sosial dipengaruhi oleh mekanisme birokrasi. Selanjutnya, penulis akan menggunakan konsep kelas dan konsep proletarianisasi untuk menjelaskan bahwa pekerja sosial merupakan kelas menengah yang telah tereksploitasi seperti kelas pekerja. Bentuk-bentuk eksploitasi yang terjadi pada pekerja sosial adalah keterlambatan pemberian gaji bulanan, ketidakcukupan besaran gaji, serta ketiadaan jaminan dan tunjangan yang dipengaruhi oleh mekanisme birokrasi. Eksploitasi ini mengakibatkan pekerja sosial mengalami proletarianisasi.

\section{PEMBAHASAN}

\section{Keterlambatan Pemberian Gaji}

Berdasarkan hasil wawancara dengan informan G yang bekerja sebagai pendamping Program Keluarga Harapan (PKH) dan informan A yang bekerja pada Program Kesejahteraan Sosial Anak (kedua informan merupakan pegawai kontrak), diperoleh informasi bahwa kedua informan ini sering mengalami keterlambatan pembayaran gaji pokok. Informan $G$ menyampaikan bahwa sejak awal bekerja, pembayaran gajinya sering ditunda (di-rapel) selama 2 sampai 4 bulan. Hal itu menyebabkan pada awal masa bekerja, ia harus menggunakan uang miliknya sendiri selama beberapa bulan untuk membiayai aktifitasnya di lapangan (biaya transportasi kunjungan ke rumah Keluarga Penerima Bantuan, dll). Ia juga menerima biaya bantuan operasional dari dinas sosial setempat (dana sharing), namun kadang pembayaran biaya tersebut juga sering tertunda selama 2 sampai 3 bulan.

Informan A menyampaikan bahwa dirinya telah mengalami keterlambatan pembayaran gaji selama dua bulan. Ia menyampaikan bahwa keterlambatan pembayaran gaji ini menyebabkan ia sering hutang untuk menutupi kekurangan dalam pemenuhan kebutuhan sehari-harinya. Informan A menyampaikan bahwa ia beruntung karena saat ini ia tinggal bersama-sama dengan orangtuanya, sehingga ia bisa meminta bantuan pada orangtuanya. Ia menyampaikan bahwa bila ia tidak tinggal dengan orangtuanya, maka ia akan sangat sulit memenuhi kebutuhannya, karena keterlambatan pembayaran gajinya.

Informan A keberatan ketika ditanya mengenai mekanisme pembayaran gajinya. Sedangkan $G$ menyampaikan bahwa setahu dia mekanisme pembayaran gaji dilakukan melalui bank setelah ia mengirim nomor rekeningnya kepada operator PKH. Kedua informan ini mengatakan bahwa 
mereka tidak tahu apa sebenarnya alasan keterlambatan tersebut secara birokratif. Mereka juga tidak tahu secara detail mengenai mekanisme birokrasi dalam pengaturan gaji mereka.

Transparansi penggunaan dan pendistribusian Biaya Bantuan Operasional bagi pendamping PKH yang dikelola oleh pemerintah daerah (dinas sosial kabupaten/kota) juga sempat menuai sejumlah kritik dari pendamping PKH di sejumlah daerah, karena biaya tersebut terlambat diberikan dan terdapat dugaan penggelapan biaya tersebut oleh pihak-pihak tertentu, sebagaimana yang dimuat oleh sejumlah media (Riau Sky, 2015; Suara Kampar, 2015; Pikiran Rakyat, 2015; Lapor, 2015; Banten Day, 2016; Go News, 2016). Kemudian berdasarkan pemberitaan Swamedia (2017), gaji yang diterima oleh para pekerja sosial yang bekerja pada Program Rehabilitasi Korban Penyalahgunaan Napza Kementerian Sosial di Bandung belum dibayar selama empat bulan. Kejadian ini selalu terjadi setiap tahun. Ikatan Pekerja Sosial Profesional Indonesia (IPSPI) tidak melakukan mediasi atau advokasi terhadap nasib mereka (Swamedia, 2017).

Secara keseluruhan, pemberitaan di media-media tersebut menunjukkan bahwa mekanisme birokrasi terkait pengaturan biaya-biaya tersebut, termasuk mengenai keterlambatan pembayaran gaji, tidak diketahui dengan jelas oleh pekerja sosial, meskipun telah dilakukan pertemuan dan diskusi terbuka dengan pemerintah daerah setempat (Riau Sky, 2015; Suara Kampar, 2015; Pikiran Rakyat, 2015; Lapor, 2015; Banten Day, 2016; Go News, 2016; Swamedia, 2017).

Berdasarkan penjelasan di atas, dapat disimpulkan bahwa mekanisme birokrasi terkait pengaturan pembayaran gaji, termasuk pemberian biaya bantuan operasional, tidak diketahui oleh para pekerja sosial yang langsung bekerja di lapangan. Padahal dalam rentang waktu keterlambatan pembayaran gaji, para pekerja sosial tetap bekerja dalam waktu kerja tertentu. Dengan kata lain, dalam rentang waktu itu, 'mereka tidak mendapat gaji'. Padahal, kebutuhan sehari-hari mereka harus tetap dipenuhi setiap hari dan mereka juga harus melunasi hutang mereka.

\section{Ketidakcukupan Besaran Gaji}

Informan Y dan M menyampaikan bahwa gaji bulanan mereka tidak cukup untuk memenuhi kebutuhan sehari-hari mereka. Mereka bekerja sebagai Satuan Tugas Perlindungan Pelayanan dan Rehabilitasi Sosial Penyandang Masalah Kesejahteraan Sosial (Satgas PPRS PMKS) di sebuah dinas sosial provinsi. Mereka menyampaikan bahwa mereka hanya menerima gaji sebesar 700 ribu sebulan. ${ }^{1}$ Mereka merupakan tenaga kontrak dan terbagi dalam beberapa

\footnotetext{
${ }^{1}$ Informan Y dan M menyampaikan agar nama wilayah kerja instansinya dirahasiakan (off the record). 
kelompok. Satu kelompok terdiri dari empat orang. Mereka bekerja selama tiga kali seminggu untuk mendata dan memantau para penyandang disabilitas mental yang berkeliaran di tempattempat umum. Wilayah kerja setiap kelompok meliputi satu kecamatan dan masing anggota kelompok bertanggungjawab atas beberapa kelurahan yang jaraknya cukup berjauhan. Meskipun jadwal kerja mereka hanya tiga kali seminggu, tenaga mereka yang keluarkan sangat besar di lapangan. Gaji yang diberikan hanya cukup untuk biaya transportasi dan tidak mencukupi untuk pemenuhan kebutuhan hidup sehari-hari. Dalam jadwal kerja tersebut, mereka kadang bekerja dari jam 8 pagi hingga jam 8 malam. Menurut Informan Y, ia melakukan pekerjaan sampingan untuk menambal kekurangan gajinya tersebut. Sedangkan informan M tidak memiliki pekerjaan sampingan dan terpaksa harus berhutang atau meminta bantuan finansial kepada orang tuanya di kampung halaman.

Sedangkan informan G, yang bekerja sebagai pendamping Program Keluarga Harapan (PKH), menyampaikan bahwa gajinya tidak mencukupi untuk memenuhi kebutuhan istri dan anaknya. Menurutnya, hal itu dikarenakan biaya bantuan operasional yang ia terima terlalu kecil, sehingga ia sering menggunakan gaji pokoknya sebagai biaya transportasinya. Bila pemberian gaji pokok dan biaya bantuan operasional terlambat, maka ia akan hutang untuk memenuhi biaya kebutuhan sehari-hari keluarganya sekaligus untuk memenuhi kebutuhannya (transportasi, dll) yang cukup banyak. Jam kerja informan G pun tidak menentu. Misalnya, ia sering melakukan kegiatan pertemuan kelompok, mencari data, atau melakukan kunjungan kepada keluarga penerima bantuan PKH pada saat sore hari hingga malam hari. Bahkan ia pernah menginap di salah satu rumah warga karena sudah larut malam.

Berdasarkan penjelasan-penjelasan tersebut, dapat disimpulkan bahwa informan G, M, dan Y telah melaksanakan kewajibannya sebagai pekerja sosial. Tetapi, besaran gaji yang mereka terima tidak sesuai dengan waktu kerja yang mereka jalani. Artinya, telah terjadi penambahan waktu kerja tanpa diimbangi dengan besaran gaji yang sesuai.

\section{Ketiadaan Jaminan dan Tunjangan}

Informan $G$ dan $A$ menyampaikan bahwa mereka telah menerima jaminan sosial ketenagakerjaan dari Badan Penyelenggara Jaminan Sosial yang meliputi jaminan kecelakaan kerja dan jaminan kematian. Kementerian Sosial yang membiayai premi jaminan sosial tersebut.

Sedangkan informan M dan Y tidak menerima jaminan sosial apa pun, karena tidak pernah mendapat informasi atau sosialisasi dari dinas sosial tempat mereka bekerja ataupun pihak-pihak lain. Mereka memang mengetahui bahwa ada program jaminan sosial dari pemerintah, baik 
kesehatan maupun tenaga kerja, namun mereka bingung mengenai besaran premi dengan gaji mereka yang hanya 700 ribu sebulan.

Informan A, G, M dan Y tidak menerima Tunjangan Hari Raya (THR). Menurut informan G, pada tahun 2016, Kementerian Sosial menjanjikan bahwa seluruh pendamping PKH akan mendapatkan gaji ke-13 sebagai THR. Akan tetapi, Kementerian Sosial tidak menepati janji tersebut karena tidak ada landasan hukum. Para pendamping PKH sempat membuat petisi untuk memprotes hal tersebut (Change, 2016a; 2016b). Kementerian Sosial lalu menerbitkan Surat Edaran Direktur Jaminan Sosial Keluarga, No. 626/LJS.JSK.TU/07/2016 tanggal 1 Juli 2016. Dalam surat tersebut dijelaskan bahwa pembayaran tunjangan terhadap pendamping dan operator PKH tidak bisa dilakukan, karena pendamping dan operator PKH tidak masuk dalam kategori satpam, pengemudi, dan petugas kebersihan (Abeng, 2016).

Surat edaran tersebut bertentangan dengan UU No 5 tahun 2014 tentang Aparatur Sipil Negara dan Peraturan Pemerintah (PP) No 11 tahun 2017 tentang Manajemen Pegawai Negeri Sipil. Dalam UU dan PP tersebut, tampak jelas bahwa para pekerja yang dikontrak oleh suatu kementerian tergolong sebagai Pegawai Negeri dengan Perjanjian Kerja (PPPK). Surat Edaran tersebut juga bertentangan dengan UU Nomor 13 tahun 2003 tentang Ketenagakerjaan. Dalam UU, jelas disampaikan bahwa para pekerja (pegawai kontrak) wajib menerima jaminan dan tunjangan. Kontradiksi ini mencerminkan bahwa di satu sisi terdapat mekanisme birokrasi yang tidak transparan, dan di sisi lain tidak ada kerjasama birokrasi di antara pihak-pihak terkait mengenai keadilan pemberian jaminan dan tunjangan.

\section{Tantangan dalam Pengembangan Profesi Pekerja Sosial di Indonesia}

Secara khusus, masalah keterlambatan pembayaran gaji, ketidakcukupan pemberian gaji, dan ketiadaan jaminan serta tunjangan, membuat informan $A, G, Y$, dan M mengemukakan bahwa mereka merasa pesimis untuk tetap menjadi pekerja sosial profesional pada program-program kesejahteraan sosial yang diselenggarakan oleh pemerintah. Informan M dan Y tidak ingin lagi memperpanjang kontrak kerja mereka. Meski demikian, mereka tetap bekerja dengan sebaikbaiknya. Ketiga masalah tersebut juga menyebabkan dua informan lain, yakni informan $\mathrm{T}$ dan F, lebih memilih untuk bekerja di luar ranah kesejahteraan sosial.

Ketiga masalah tersebut juga menunjukkan bahwa informan A, G, Y, dan M telah mengalami eksploitasi. Dengan kata lain, bentuk-bentuk eksploitasi yang terjadi pada mereka adalah keterlambatan pemberian gaji bulanan, ketidakcukupan besaran gaji, serta ketiadaan jaminan dan tunjangan. Eksploitasi ini disebabkan oleh mekanisme birokrasi yang tidak transparan. Eksploitasi inilah yang kemudian menunjukkan bahwa sebagai pekerja sosial, informan A, G, Y, 
dan M, telah mengalami proletarianisasi. Melalui proletarianisasi, para pekerja sosial adalah kelas menengah yang telah tereksploitasi seperti kelas pekerja (buruh). Para pekerja sosial, dalam konteks ini, pun dapat dikategorikan sebagai bagian dari kelas pekerja yang bekerja atas nama pemerintahan (negara).

Berdasarkan waktu penelitian, ketiga masalah tersebut muncul pada tahun 2017. Meski demikian, ketiga masalah itu bisa saja terus terjadi hingga saat ini (tahun 2019). Apabila saat ini ketiga masalah tersebut belum dapat diatasi secara efektif dan menyeluruh, maka ketiga masalah itu dapat menjadi tantangan yang cukup berat bagi pengembangan profesi pekerja sosial di Indonesia.

Pada tahun 2019 ini, pemerintah telah mengesahkan UU Nomor 14 Tahun 2019 tentang Praktik Pekerjaan Sosial. UU ini dapat menjadi landasan awal untuk mengatasi ketiga masalah tersebut, sehingga pengembangan profesi pekerja sosial di Indonesia menjadi lebih progresif. Dalam konteks ini, kesejahteraan pekerja sosial harus sejalan dengan kesejahteraan para penerima bantuan program-program kesejahteraan sosial.

\section{SIMPULAN}

Hasil penelitian ini menunjukkan bahwa para pekerja sosial telah mengalami eksploitasi. Bentuk eksploitasi yang mereka alami adalah keterlambatan pemberian gaji bulanan, ketidakcukupan besaran gaji, serta ketiadaan jaminan dan tunjangan. Eksploitasi ini disebabkan oleh mekanisme birokrasi yang tidak transparan Eksploitasi ini dapat menjadi tantangan dalam pengembangan profesi pekerja sosial di Indonesia.. Di sisi lain, eksploitasi ini juga menunjukkan bahwa para pekerja sosial telah mengalami proletarianisasi. Dalam proletarianisasi, para pekerja sosial adalah kelas menengah yang telah tereksploitasi seperti kelas pekerja (buruh). Undang-undang Nomor 14 tahun 2019 tentang Praktik Pekerjaan Sosial dapat menjadi landasan awal untuk mengatasi eksploitasi tersebut, sehingga pengembangan profesi pekerja sosial di Indonesia menjadi lebih progresif.

\section{DAFTAR PUSTAKA}

Abeng Pangestu. (2016) "Surat Terbuka untuk Menteri Sosial (Ibunda Khofifah Indar Parawansa)." Diakses 19 Agustus 2017

(http://art4beng.blogspot.com/2016/07/surat-terbuka-untuk-menteri-sosial.html).

Ambercrombie, Nicholas., Stephen Hill, dan Bryan S. Turner. (2010). Kamus Sosiologi. Yogyakarta: Pustaka Pelajar.

Anderson, William A., dan Patricia Yancey Martin. (1983). "Bureaucracy and Professionalism in the Social Services." Journal of Social Service Research (5): 33-50. 
Antara Gorontalo. (2016). “Gorontalo Utara Akan Naikkan Honor Tenaga PKH.” Diakses 19 Agustus 2017 (http://m.antaragorontalo.com/berita/27321/gorontalo-utara-akannaikkan-honor-tenaga-pkh).

Banten Day. (2016). "Pendamping PKH Pertanyakan Dana Sharing Dari Pemkab Lebak." Diakses pada 19 Agustus 2017. (http://bantenday.com/pendamping-pkhpertanyakan-dana-sharing-dari-pemkab-lebak/)

Bottomore, Tom. (1991). "Middle Class." Hal. 378-379 dalam A Dictionary of Marxist Thought, Tom Bottomore (ed). Oxford: Blackwell.

Boudon, Raymond., dan Francois Bouriccaud. (1989). A Critical Dictionary Of Sociology. Chicago: Routledge.

Change. (2016). "Petisi: Tolong Berikan Hak Atas Gaji Dan Tepati Janji Gaji 13 untuk Pendamping dan Operator PKH.” Diakses pada 19 Agustus 2017. (https://www.change.org/p/kementrian-sosial-ri-tolong-berikan-hak-atas-gaji-dantepati-janji-gaji-13-untuk-pendamping-operator-pkh).

Change. (2016). Petisi: Aksi Sejuta Payung untuk Kementerian Sosial. Diakses pada 19 Agustus 2017 (https://www.change.org/p/uppkh-aksi-sejuta-payung-untukkemensos).

Corrigan, Paul., dan Peter Leonard. (1978). Social Work Practice Under Capitalism: A Marxist Approach. London: MacMillan

Damanik, Juda. (2008). Pekerjaan Sosial untuk SMK: Jilid 1. Jakarta: Departemen Pendidikan Nasional.

Ellis, Kathryn. (2009). "Direct Payments and Social Work Practice: The Significance of StreetLevel Bureaucracy in Determining Eligibility." British Journal of Social Work (37): 405422.

Fahrudin, Adi. (2012). Pengantar Kesejabteraan Sosial. Bandung: Refika Aditama.

Go News. (2016). "Kecewa dengan Disosnaker, Pendamping PKH Meranti Ngadu ke DPRD.” Diakses 19 Agustus 2017.

(https://www.gonews.co/berita/baca/2016/09/09/kecewa-dengan-disosnakerpendamping-pkh-meranti-ngadu-ke-dprd/)

Goodsell, Charles. (2005). “The Bureau as Unit of Governance.” Hal. 17-40 dalam The V alues Of Bureaucracy, Paul Du Gay (ed). Oxford: Oxford University Press.

Gough, Ian. (1972). "Marx's Theory of Productive and Unproductive Labour." New Left Review (1):47-72.

Lapor (Layanan Aspirasi dan Pengaduan Rakyat). (2015). "Gaji Pendamping PKH Belum Dicairkan.” Diakses 19 Agustus 2017. (https://www.lapor.go.id/).

Lefort, Claude. (1986). The Political Forms of Modern Society: Bureaucracy, Democracy, Totalitarianism. Cambridge: MIT Press

Marx, Karl. (1968). Theories of Surplus V alue Vol. 2. Moscow: Foreign Language Publishing House.

Marx, Karl. (2010). Capital Vol 1.London: Lawrence \& Wishart..

Marx, Karl. (2010). Capital Vol 3. London: Lawrence \& Wishart..

Miles, Matthew B., dan A Michael Huberman. (1992). Analisis Data Kualitatif. Jakarta: Penerbit Universitas Indonesia.

Peraturan Pemerintah No 11 Tahun 2017 tentang Manajemen Pegawai Negeri Sipil.

Pikiran Rakyat. (2015). "Insentif Pendamping PKH di KBB Belum Cair Selama 6 Bulan." Diakses 19 Agustus 2017 (http://www.pikiran-rakyat.com/bandung- 
raya/2015/06/29/332929/insentif-pendamping-pkh-di-kbb-belum-cair-selama-6bulan).

Riau Sky. (2015) "Malangnya Nasib PKH di Kampar, Gaji Cuma Rp350 Ribu, Minta Laptop Malah Dikasih Flashdisk.” Diakses 19 Agustus 2017.

(http:/ / riausky.com/news/detail/16235/malangnya-nasib-pkh-di-kampar..-gaji-cumarp350-ribu,-minta-laptop-malah-dikasih-flashdisk.html).

Soehartono, Irawan. (2003). "Perkembangan Pekerjaan Sosial Profesional dan Konsepsi Penanganan Masalah.” Hal 35-48 dalam Isu Kesejabteraan Sosial, Abu Huraeah (ed). Bandung: Ceplas FISIP Universitas Pasundan.

Suara Kampar. (2015). "Pendamping PKH: Dana Sharing Hanya Untungkan Dinas Sosial Kampar.” Diakses 19 Agustus 2017 (http:/ / suarakampar.com/berita-pendampingpkh--dana-sharing-hanya-untungkan-dinas-sosial-kampar--.html)

Swamedia. (2017). "Pekerja Lembaga Rehabilitasi Napza Kemensos di Bandung, 4 Bulan Tidak Digaji.” Diakses 19 Agustus 2017

(http://www.swamedium.com/2017/04/24/pekerja-lembaga-rehabilitasi-napzakemensos-di-bandung-4-bulan-tidak-digaji/).

Tilly, Charles. (1979). "Proletarianization: Theory and Research.” CRSO Working Paper No. 202. Center for Research on Social Organization: University of Michigan.

Trikha, Rajeshwar. (2009). Bureaucracy and Public Administration. Jaipur: ABD Publishers

Undang-Undang Nomor 5 Tahun 2014 tentang Aparatur Sipil Negara.

Undang-Undang Nomor 11 Tahun 2009 tentang Kesejahteraan Sosial.

Undang-Undang Nomor 13 Tahun 2003 tentang Ketenagakerjaan.

Undang-Undang Nomor 14 Tahun 2019 tentang Praktik Pekerjaan Sosial.

Undang-Undang Nomor 6 Tahun 1974 tentang Ketentuan-Ketentuan Pokok Kesejahteraan Sosial.

Weber, Max. (1946). Essays in Sociology. New York: Oxford University Press.

Weber, Max. (1978). Economy and Society. Berkeley: University of California Press.

Wright, Eric Ollin. (2009).’'Understanding Class: Towards an Integrated Analytical Approach." New Left Review (60): 101-116. 